\title{
ANALISIS KESALAHAN SISWA DALAM MENYELESAIKAN SOAL PISA KONTEN UNCERTAINTY AND DATA
}

\author{
Evi Fazzilah ${ }^{1}$, Kiki Nia Sania Effendi ${ }^{2}$, Rina Marlina ${ }^{3}$ \\ 1, 2, 3 Program Studi Pendidikan Matematika FKIP UNSIKA, Jl. HS. Ronggowaluyo, Telukjambe Timur Karawang \\ 1610631050052@student.unsika.ac.id
}

\begin{abstract}
The importance of literacy and the low ranking of Indonesian students on PISA results is due to the many mistakes made by students. The study aims to determine type of error made by students in solving uncertainty and data content pisa questions. The research was conducted with using a descriptive qualitative approach. From 20 students of VIII MIPA 2 in one of public middle school which is located in the sub-district Telukjambe Timur school year 2019/2020 taken 4 students as a research subject. Test instrument used in the research was a test. The conclusions obtained from the results of the study are: (1) misunderstanding the problem as much $15 \%$, because less thorough in understanding (2) transformasi errors as much 55\%, because wrong formula (3) process skill errors as much $35 \%$ and (4) determining the final error as much $50 \%$, because write a conclusion but it's not right. Based on research results then the type of errors is obtained more done by students in solving uncertainty and data content pisa questions is transformation.
\end{abstract}

Keywords: Error Analysis, PISA, Uncertainty and Data

\begin{abstract}
Abstrak
Pentingnya literasi dan rendahnya peringkat siswa Indonesia pada hasil PISA yang disebabkan banyaknya kesalahan yang dilakukan oleh siswa. Penelitian ini bertujuan untuk mengetahui jenis kesalahan yang dilakukan oleh siswa dalam menyelesaikan soal PISA konten Uncertainty and Data. Penelitian ini dilakukan dengan menggunakan pendekatan kualitatif deskriptif. Dari 20 siswa kelas VIII MIPA 2 di salah satu SMP Negeri yang terletak di kecamatan Telukjambe Timur Tahun Ajaran 2019/2020 diambil 4 siswa sebagai subjek penelitian. Instrumen yang digunakan penelitian berupa tes. Kesimpulan yang didapat dari hasil penelitian adalah: (1) kesalahan memahami masalah sebanyak 15\%, karena kurang teliti dalam memahami masalah (2) kesalahan transformasi sebanyak 55\%, karena salah menentukan rumus (3) kesalahan keterampilan proses sebanyak 35\%, dan (4) kesalahan penentuan jawaban akhir sebanyak 50\%, karena menuliskan kesimpulan tetapi tidak tepat. Berdasarkan hasil penelitian maka diperoleh jenis kesalahan yang lebih banyak dilakukan oleh siswa dalam menyelesaikan soal PISA konten Uncertainty and Data adalah transformasi.
\end{abstract}

Kata kunci: Analisis Kesalahan, PISA, Uncertainty and Data

\section{PENDAHULUAN}

Kesalahan adalah fenomena yang menyimpang dari kebenarannya. Hal tersebut sesuai dengan pernyataan menurur Rosyidi dalam (Laeli, 2017) yang menyatakan bahwa definisi kesalahan adalah sebuah bentuk penyimpangan terhadap hal yang telah dianggap benar berdasarkan prosedur yang ditetapkan sebelumnya. Hal tersebut sesuai dengan (Mubarok et al., 2017) yang mengemukakan bahwa kesalahan adalah penyimpangan dari jawaban yang sebenarnya dan bersifat sistematis.

Banyak penyebab dari kesalahan yang dilakukan oleh siswa dalam menyelesaikan masalah khususnya matematika. Menurut Malau dalam (Nugrahani, 2016) menjelaskan bahwa penyebab dari terjadinya kesalahan yang sering dilakukan oleh siswa pada saat menyelesaikan soal-soal matematika antara lain adalah kurangnya pemahaman atas materi yang dipelajari, kurangnya penguasaan dalam bahasa matematika, keliru dalam menafsirkan atau menerapkan rumus, salah perhitungan, kurang teliti, atau lupa konsep. 
Prosedur kesalahan Newman dalam (Husna, 2017) yang terdiri dari 4 kategori yaitu: (1) Pemahaman (comprehension), (2) Transformasi (transformation), (3) Keterampilan proses (process skill), (4) Penentuan jawaban akhir (encoding). Siswa dapat dinyatakan salah dalam memahami masalah apabila siswa tidak paham dari arti keseluruhan soal dan Siswa tidak dapat menuliskan atau menjelaskan apa yang diketahui dan yang ditanyakan dari soal. Siswa salah dalam transformasi apabila siswa tidak dapat menentukan rumus yang akan digunakan untuk menyelesaikan soal, siswa tidak dapat menentukan operasi matematika atau rangkaian operasi untuk menyelesaikan masalah dalam soal dengan tepat dan siswa tidak dapat mengidentifikasi operasi, atau serangkaian operasi. Siswa melakukan kesalahan keterampilan proses apabila siswa tidak dapat mengetahui proses untuk menyelesaikan soal meskipun telah berhasil menentukan rumus dengan tepat dan siswa tidak dapat menjalankan prosedur dengan benar meskipun telah mampu menentukan operasi matematika yang digunakan dengan tepat. Kemudian jika siswa melakukan kesalahan dalam penentuan jawaban akhir apabila siswa tidak dapat menuliskan jawaban yang ia maksudkan dengan tepat sehingga menyebabkan berubahnya makna yang ia tulis, Siswa tidak dapat mengungkapkan solusi dari soal yang ia kerjakan dalam bentuk tertulis yang dapat diterima, dan siswa tidak dapat menuliskan kesimpulan dengan tepat hasil pekerjaannya.

Pengaktifan literasi matematika sangat diperlukan untuk dapat meminimalisir kesalahan yang dilakukan siswa dalam menyelesaikan masalah khususnya yang berkaitan dengan penerapan matematika dalam kehidupan sehari-hari. Literasi merupakan kemampuan yang dimiliki individu untuk memahami, menggunakan sesuatu secara cerdas melalui membaca, melihat, menulis, dan berbicara yang tidak terlepas dari konteks di mana kemampuan itu diperoleh dan dari siapa memperolehnya (Effendi et al., 2018)

Pentingnya literasi juga di kemukakan oleh (Johar, 2012) bahwa pengetahuan dan pemahaman mengenai konsep matematika sangatlah penting, tetapi lebih penting lagi mengaktifkan kemampuan literasi matematika untuk dapat memecahkan permasalahan yang dihadapi dalam kehidupan seharihari. Dengan demikian dapat disimpulkan bahwa literasi adalah kemampuan yang harus dimiliki oleh masing-masing individu, sehingga dapat memecahkan masalah yang ditemukan dalam kehidupan sehari-hari.

PISA (Programme for International Student Assessment) adalah salah satu program penilaian tingkat internasional pada siswa yang berumur 15 tahun serta telah memperoleh pengetahuan dan keterampilan penting untuk berpartisipasi penuh dalam masyarakat modern, PISA diselenggarakan selama 3 tahun sekali dengan fokus pada pelajaran inti sekolah yaitu membaca, matematika dan sains, terdiri dari 4 konten yaitu konten ruang dan bentuk (space and shape), konten perubahan dan hubungan (change and relationship), konten bilangan (quantity), serta konten ketidakpastian dan data (uncertainty and data) (OECD, 2019).

OECD dalam (Husna, 2017) Siswa Indonesia pada tahun 2006 sampai tahun 2012 peringkat Indonesia terus mengalami penurunan drastis yaitu peringkat 64 dari 65 negara, Indonesia mengalami 
peningkatan yakni berada di posisi 62 dari 70 negara pada tahun 2015, kemudian Indonesia kembali mengalami penurunan peringkat pada tahun 2018 yaitu peringkat 72 dari 77 negara. Berikut adalah peringkat siswa Indonesia pada hasil PISA tahun 2000 sampai dengan tahun 2018.

\section{Tabel 1.}

Peringkat siswa Indonesia pada PISA

\begin{tabular}{|l|c|c|}
\hline Tahun & Peringkat & Negara \\
\hline 2000 & 39 & 41 \\
\hline 2003 & 38 & 40 \\
\hline 2006 & 50 & 57 \\
\hline 2009 & 61 & 65 \\
\hline 2012 & 64 & 65 \\
\hline 2015 & 62 & 70 \\
\hline 2018 & 72 & 77 \\
\hline
\end{tabular}

Siswa kurang berlatih dalam memecahkan masalah dan menyelesaikan soal berkarakteristik dapat menjadikan sebab dari rendahnya peringkat siswa, contohnya seperti perolehan peringkat siswa Indonesia pada hasil PISA. Purnomo \& Dafik (Mansur, 2018) mangemukakan bahwa salah satu faktor penyebab rendahnya hasil PISA adalah siswa Indonesia pada umumnya kurang terlatih dalam menyelesaikan soal-soal dengan karakteristik seperti soal-soal PISA.

Muhadjir Effendy dalam (Setiawan, 2019) selaku Menteri Pendidikan dan Kebudayaan 20162019 mengemukakan bahwa pendidikan di Indonesia harus berstandar internasional, ada lembagalembaga internasional yang melakukan standardisasi kemudian mendapat pengakuan dari negara lain sehingga mendapatkan recognition, dan memilih PISA untuk dijadikan standardisasi internasional, penilaian hasil dari tes PISA antara beberapa negara yang memiliki populasi siswanya kecil dibandingkan dengan Indonesia yang sangat banyak, paling kontras jika dibandingkan dengan negara Singapura yang berada pada posisi paling tinggi, sementara Indonesia terendah.

Kategori kesalahan Newman memiliki kesamaan dengan strategi pemecahan masalah Polya, sehingga dapat digunakan untuk menganalisis kesalahan siswa dalam memecahkan masalah soal PISA konten Uncertainty and Data. Berdasarkan uraian tersebut, maka permasalahan yang dapat ditemukan oleh peneliti adalah apa jenis kesalahan yang dilakukan oleh siswa dalam menyelesaikan soal PISA konten Uncertainty and Data.

\section{METODE}

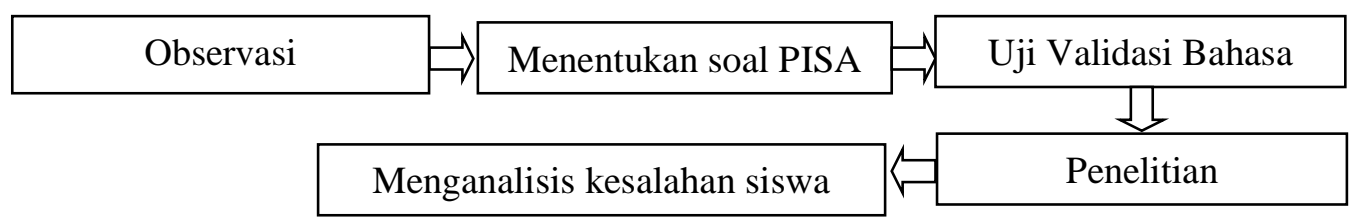

Gambar 1. Bagan Alir Prosedur Penelitian 
Jenis metode penelitian yang digunakan adalah pendekatan kualitatif dengan menggunakan metode deskriptif. Menurut Bog dan Taylor (Moleong, 2017) mendefinisikan bahwa penelitian kualitatif sebagai prosedur penelitian yang menghasilkan data deskriptif yaitu berupa kalimat yang tertulis atau lisan dari orang-orang dan perilaku yang diamati berdasarkan dengan fenomena yang terjadi.

Peneliti memilih untuk menggunakan pendekatan kualitatif dikarenakan permasalahan terjadinya suatu fenomena memiliki banyak makna, sehingga tidak mungkin data dari fenomena tersebut diolah dengan menggunakan sebuah penelitian dengan pendekatan kuantitatif. Tujuan dari penelitian ini adalah untuk mendeskripsikan jenis kesalahan yang dilakukan oleh siswa dalam menyelesaikan soal PISA konten Uncertainty and Data berdasarkan dengan prosedur Newman.

Penelitian ini dilaksanakan di kelas VIII MIPA 2 dari salah satu SMP Negeri yang terletak di kecamatan Telukjambe Timur yakni dengan jumlah 20 siswa. Pemilihan subjek penelitian menggunakan teknik Purposive Sampling. Purposive Sampling adalah teknik pengambilan sampel dengan pertimbangan tertentu (Sugiyono, 2018). Peneliti akan mengambil 10\% dari 20 siswa, sehingga diperoleh 4 siswa. hal tersebut sesuai dengan pendapat (Arikunto, 2013) yaitu penentuan pengambilan sampel dapat dilakukan jika jumlah subyeknya besar maka dapat diambil $10 \%$ hingga $15 \%$.

Teknik pengumpulan data yang digunakan dalam penelitian ini meliputi tes berupa soal uraian. Tes tersebut dilaksanakan dengan tujuan untuk dapat mengetahui jenis kesalahan yang dilakukan oleh siswa dalam menyelesaikan soal PISA konten Uncertainty and Data. Instrumen yang digunakan dalam penelitian ini adalah tes. Tes tersebut berupa 1 butir terjemahan soal PISA konten Ucertainty and Data yang telah divalidasi oleh ahli bahasa dan diadaptasi dari PISA 2018 Assessment and Analytical Framework. Paris.

Teknik analisis data yang digunakan dalam penelitian ini adalah Miles dan Huberman dalam (Sugiyono, 2018) yang dilakukan meliputi 3 tahap, yaitu: (1) reduksi data yaitu tahap peneliti melakukan penggolongan data, membuang data yang tidak perlu sehingga dapat diverifikasi, data tersebut berupa hasil jawaban siswa, (2) penyajian data yaitu sekumpulan informasi yang telah tersusun dan member kemungkinan adanya penarikan kesimpulan serta pengambilan tindakan, (3) kesimpulan yaitu pengambilan intisari dan sajian ata yang terorgansasi dalam sebuah pernyataan kalimat yang singkat.

Data yang diperoleh dari penelitian ini berupa jwaban siswa kelas VIII MIPA 2 dalam memecahkan masalah pada soal PISA konten Uncertainty and Data. Berdasarkan hasil jawaban siswa, selanjutnya akan dikoreksi untuk dapat mengetahui jenis kesalahan yang dilakukan oleh siswa sesuai dengan prosedur Newman.

\section{HASIL}

Penelitian ini dilaksanakan pada siswa kelas VIII dari salah satu sekolah SMP Negeri yang 
terletak di kecamatan Telukjambe Timur. Tes yang digunakan dalam penelitian ini adalah hasil terjemahan soal PISA konten Uncertainty and Data yang sebelumnya telah divalidasi oleh ahli. Tes tersebut dilaksanakan dengan tujuan untuk dapat mengetahui jenis kesalahan yang dilakukan oleh siswa, jenis kesalahan tersebut akan dianalisis berdasarkan prosedur kesalahan Newman. Berikut adalah soal PISA konten Uncertainty and Data yang digunakan dalam penelitian ini:

\begin{tabular}{|c|c|c|}
\hline \multicolumn{3}{|c|}{$\begin{array}{l}\text { Perusahaan Electrix membuat dua jenis peralatan elektronik: pemutar video dan pemutar } \\
\text { suara. Pada akhir produksi harian, pemutar-pemutar tersebut diuji dan jika ada pemutar } \\
\text { yang rusak maka pemutar itu akan dikirim untuk diperbaiki. } \\
\text { Tabel berikut menunjukkan rata-rata jumlah pemutar dari setiap jenis yang dibuat per hari, } \\
\text { dan persentase rata-rata pemutar yang rusak per hari. }\end{array}$} \\
\hline Tipe pemutar & $\begin{array}{l}\text { Rata-rata jumlah pemutar } \\
\text { yang dibuat per hari }\end{array}$ & $\begin{array}{l}\text { Persentase rata-rata pemutar } \\
\text { yang rusak per hari }\end{array}$ \\
\hline pemutar video & 2000 & $5 \%$ \\
\hline pemutar suara & 6000 & $3 \%$ \\
\hline \multicolumn{3}{|c|}{$\begin{array}{l}\text { Pertanyaan : } \\
\text { Salah satu penguji berpendapat bahwa: } \\
\text { "Rata-rata, ada lebih banyak pemutar video yang dikirim untuk diperbaiki per hari } \\
\text { dibandingkan dengan jumlah pemutar suara yang dikirim untuk diperbaiki per hari" } \\
\text { Putuskan apakah pendapat penguji itu benar atau tidak. Berikan argumen matematis untuk } \\
\text { mendukung jawaban kamu. }\end{array}$} \\
\hline
\end{tabular}

Gambar 2. Soal Penelitian

Adapun indikator kesalahan berdasarkan prosedur Newman, yaitu: (1) memahami masalah (comprehension), (2) transformasi (transformation), (3) keterampilan proses (process skill), dan (4) Penentuan jawaban akhir (encoding). Hasil analisis data menunjukkan bahwa persentase kesalahan berdasarkan prosedur Newman adalah seba yang telah dilakukan oleh siswa adalah sebagai berikut.

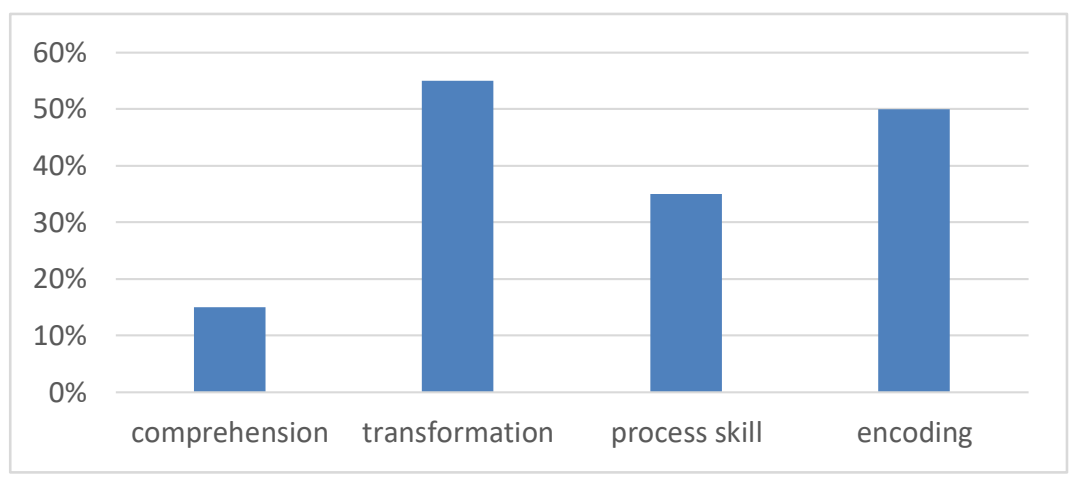

Gambar 3. Persentase kesalahan berdasarkan prosedur Newman 
Berdasarkan gambar 3 maka dapat diperoleh persentase kesalahan dalam memahami masalah (comprehension) sebanyak 15\%, kesalahan transformasi (transformation) sebanyak 55\%, kesalahan keterampilan proses (process skill) sebanyak 35\%, dan penentuan jawaban akhir (encoding) sebanyak 50\%. Hal ini sejalan dengan hasil penelitian (Fatimah, 2017) yang menyatakan bahwa kategori kesalahan transformasi sebesar 67,46\% merupakan kesalahan yang paling banyak dilakukan oleh siswa jika dibandingkan dengan kategori kesalahan yang lainnya.

Dari data persentase kesalahan berdasarkan prosedur Newman, dapat diketahui bahwa siswa lebih banyak melakukan kesalahan dalam transformasi. Setelah hasil tes dianalisis, maka dapat ditentukan subjek penelitiannya dengan cara purposive sampling yaitu mengambil 1 siswa sebagai subjek penelitian dari masing-masing jenis kesalahan prosedur Newman. Peneliti menggunakan inisial nama sebagai kode siswa yang telah menyelesaikan soal tes berupa hasil terjemahan soal PISA konten Uncertainty and Data. Berikut ini adalah subjek penelitian yang dipilih:

\section{Tabel 2.}

Kesalahan subjek penelitian

\begin{tabular}{|c|c|}
\hline Kode Subjek & Jenis Kesalahan \\
\hline NRP & Memahami Masalah \\
\hline AP & Transformasi \\
\hline SS & Keterampilan Proses \\
\hline RO & Penentuan Jawaban Akhir \\
\hline
\end{tabular}

Subjek yang dipilih diatas akan dianalisis berdasarkan dengan prosedur Newman sesuai dengan jawabannya masing-masing. Berikut adalah soal hasil terjemahan PISA konten Uncertainty and Data yang telah divalidasi oleh ahli bahasa:

Soal tersebut tentang membuat keputusan benar atau tidak terhadap pendapat dari salah satu penguji mengenai perbandingan antara pemutar video dan pemutar suara, apakah lebih banyak pemutar video yang dikirim untuk diperbaiki perhari dibandingkan dengan jumlah pemutar suara yang dikirim untuk diperbaiki per hari. Dimana untuk pemutar video memiliki Rata-rata jumlah pemutar yang dibuat per hari sebanyak 2000 dengan Persentase rata-rata pemutar yang rusak per hari sebanyak $5 \%$, dan untuk pemutar suara memiliki Rata-rata jumlah pemutar yang dibuat per hari sebanyak 6000 dengan Persentase rata-rata pemutar yang rusak per hari sebanyak 3\%.

Berikut adalah analisis terhadap subjek yang dipilih:

- Subjek NRP

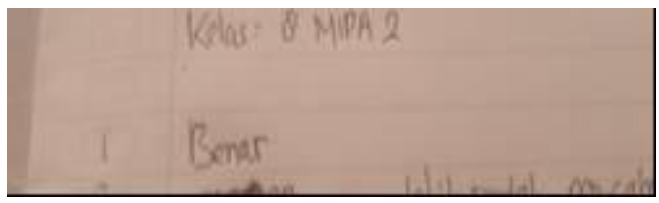

Gambar 4 Jawaban Subjek NRP

Subjek NRP melakukan kesalahan dalam memahami soal. Hal ini dapat dilihat dari gambar 4 
bahwa subjek kurang teliti dalam memahami masalah pada saat menyelesaikan soal. Hal ini sejalan dengan hasil penelitian yang telah dilakukan oleh (Sumargiyani et al., 2020) yang menyatakan bahwa mahasiswa kurang teliti dalam memahami masalah.

Dapat dilihat dari jawaban siswa yaitu hanya dengan memutuskan pendapat penguji tersebut "Benar", tanpa memberikan argumen sesuai dengan perintah yang terdapat pada soal. Seharusnya siswa juga menyertakan argumen yang mendukung jawabanya, esuai dengan perintah pada soal.

- Subjek AP

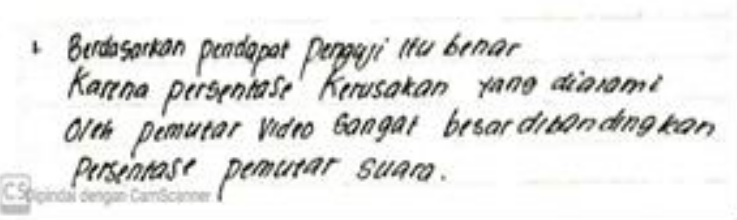

Gambar 5. Jawaban Subjek AP

Subjek AP telah mampu memahami masalah, hal tersebut dapat dilihat dari jawaban subjek yang menyatakan pendapat penguji tersebut benar, dan menyertakan argumen sesuai dengan perintah yang terdapat pada soal.

Subjek melakukan kesalahan dalam menentukan rumus yang akan digunakan untuk menyelesaikan soal sehingga mengakibatkan siswa melakukan kesalahan transformasi. Hal ini sejalan dengan penelitian yang telah dilakukan oleh (Siswandi et al., 2016) bahwa siswa melakukan kesalahan dalam menentukan rumus.

Bedasarkan gambar 5, subjek menyelesaikan soal berdasarkan dengan besaran persentase rata-rata pemutar yang rusak per hari dari masing-masing jenis pemutar. Untuk pemutar suara memiliki persentase rata-rata pemutar yang rusak per hari sebanyak 3\%, sedangkan pemutar video memiliki persentase rata-rata pemutar yang rusak per hari sebanyak 5\%. Seharusnya subjek mencari hasil dari persentase rata-rata pemutar yang rusak per hari dikali dengan rata-rata jumlah pemutar yang dibuat perhari dari masing-masing pemutar, sehingga hasil operasi hitung tersebut dapat dijadikan sebagai argumen. Pemutar suara memiliki persentase rata-rata pemutar yang rusak per hari 3\% atau (3 dibagi 100) dikali $6000=180$, sedangkan pemutar video memiliki persentase rata-rata pemutar yang rusak per hari 5\% atau (5 dibagi 100) dikali $2000=100$. Berdasarkan hasil perhitungan tersebut dapat dilihat bahwa pendapat penguji tersebut adalah "salah".

- Subjek SS

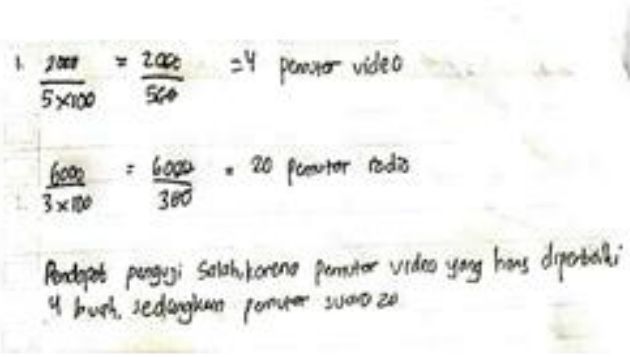

Gambar 6. Jawaban Subjek SS 
Subjek SS telah mampu memahami masalah dan transformasi. Subjek melakukan kesalahan dalam mengubah bentuk persentase kedalam bentuk pecahan, sehingga mengakibatkan siswa melakukan kesalahan dalam keterampilan Proses. Hal ini sejalan dengan hasil penelitian Jha dalam (Paladang et al., 2018) bahwa siswa siswa tidak mengetahui proses untuk menyelesaikan soal meskipun telah menggunakan rumus dengan tepat.

Dapat dilihat dari gambar 6, bahwa subjek menyelesaikan soal dengan menggunakan langkah penyelesaian yang salah. Hal tersebut dapat dilihat dari jawaban siswa bahwa untuk mencari hasil persentase adalah dengan membagi rata-rata jumlah pemutar yang dibuat perhari dan persentase ratarata pemutar yang rusak perhari. pemutar video memiliki rata-rata jumlah pemutar yang dibuat perhari sebanyak 2000 dibagi (5 dikali 100) sama dengan 2000 dibagi 500 atau sama dengan 4 pemutar video, sedangkan pemutar suara memiliki rata-rata jumlah pemutar yang dibuat perhari sebanyak 6000 dibagi (3 dikali 100) sama dengan 6000 dibagi 300 atau sama dengan 20 pemutar suara. Berdasarkan hasil perhitungan subjek tersebut, pendapat penguji adalah "salah", karena pemuar video yang harus diperbaiki 4 buah sedangkan pemutar suara 20.

Seharusnya siswa melakukan langkah perhitungan dengan tepat, yaitu rata-rata jumlah pemutar yang dibuat perhari dikali dengan persentase rata-rata pemutar yang rusak perhari. Pemutar suara memiliki persentase rata-rata pemutar yang rusak per hari 3\% atau (3 dibagi 100) dikali 6000 sama dengan 180, sedangkan pemutar video memiliki persentase rata-rata pemutar yang rusak per hari 5\% atau (5 dibagi 100) dikali 2000 sama dengan 100. Sehingga dapat disimpulkan bahwa argumen penguji tersebut adalah "salah".

- Subjek RO

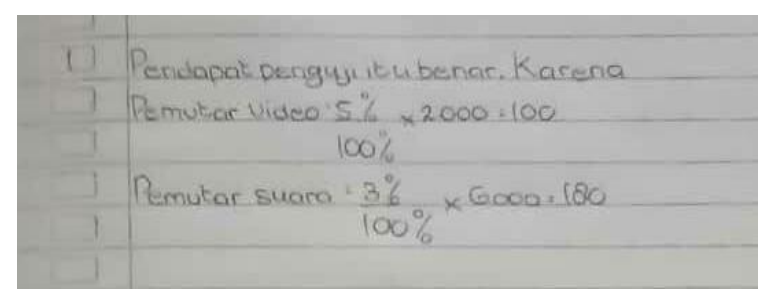

Gambar 7. Jawaban Subjek RO

Subjek RO telah mampu memahami masalah, transformasi dan keterampilan proses. Subjek melakukan kesalahan dalam menuliskan kesimpulan tetapi tidak tepat sehingga mengakibatkan kesalahan penentuan jawaban akhir. Hal ini sejalan dengan hasil penelitian yang telah dilaksanakan (Fatahillah et al., 2017) bahwa siswa melakukan kesalahan penentuan jawaban akhir karena tidak menuliskan kesimpulan dan menuliskan kesimpulan tetapi tidak tepat.

Dapat dilihat berdasarkan jawaban siswa yang melakukan kesalahan dalam mengambil kesimpulan dari hasil operasi hitung yang telah dilakukan. Siswa menuliskan bahwa pendapat penguji tersebut adalah "benar". Seharusnya siswa menuliskan bahwa pendapat penguji tersebut adalah "salah" karena berdasarahkan hasil dari perhitungan yang telah siswa lakukan ada lebih banyak pemutar suara yang dikirim untuk diperbaiki perhari yaitu sebanyak 180, sedangkan pemutar video memiliki 100 
pemutar yang dikirim untuk diperbaiki perhari.

\section{KESIMPULAN}

Berdasarkan hasil analisis kesalahan berdasarkan prosedur Newman, siswa kelas VIII MIPA 2, kesalahan terbesar yang dilakukan oleh siswa yaitu jenis kesalahan Transformasi (Transformation) yaitu dengan persentase sebesar 55\%. Siswa lebih banyak melakukan kesalahan dalam menentukan rumus yang akan digunakan dalam menyelesaikan soal. Kesalahan tersebut disebabkan karena siswa menggunakan rumus yang salah dalam menyelesaikan soal, kurang memahami materi prasyarat, kurang teliiti, dan terlalu terburu-buru dalam menyelesaikan soal.

\section{DAFTAR PUSTAKA}

Arikunto, S. 2013. Dasar-Dasar Evaluasi Pendidikan. Jakarta: Bumi Aksara.

Effendi, K. N. S., Putri, R. I. I., Zulkardi, \& Yaniawati, P. (2018). Analisis penerapan gerakan literasi sekolah dan konteks permainan futsal dalam pembelajaran matematika. Ed-Humanistics.

Fatahillah, A., Wati, Y. F., \& Susanto. (2017). Analisis Kesalahan Siswa dalam Menyelesaikan Soal Cerita Matematika berdasarkan Tahapan Newman beserta Bentuk Scaffolding yang diberikan. Kadikma.

Fatimah, S. (2017). Analisis Kesalahan Siswa Sekolah Menengah Pertama Dalam Menyelesaikan Soal Cerita Pada Materi Kubus Dan Balok Kelas Viii Smp Negeri 1 Sambi Boyolali.

Husna, I. (2017). Analisis Kesalahan Siswa dalam Memecahkan Soal Matematika Model PISA Konten Uncertainty and Data. Seminar Nasional Pendidikan Matematika.

Johar, R. (2012). Domain Soal Pisa Untuk Literasi Matematika. Jurnal Peluang, 1(1), 30.

Laeli, H. (2017). Deskripsi Kesalahan Siswa Kelas VII SMP N Kebasem Dalam Menyelesaikan Soal Operasi Hitung Bilangan Bulat. Skripsi, 6-24.

Mansur, N. (2018). Melatih Literasi Matematika Siswa dengan Soal PISA. Prisma.

Moleong, L. J. 2017. Metodologi Penelitian Kualitatif. Bandung: PT. Remaja Rosdakarya

Mubarok, Hidayanto, E., \& As'ari, A. R. (2017). Kesalahan Siswa dalam Menyelesaikan Soal Pemecahan Masalah. Proseding Seminar Nasional Matematika Dan Pembelajaran 2017.

Nugrahani, A. (2016). Analisis Kesalahan Dalam Menyelesaikan Soal Cerita Pada Materi Himpunan Berdasarkan Tahapan Newman Pada Siswa Kelas Vii A Smpkristen Satya Wacana Salatiga.

OECD. (2019). PISA 2018 Assessment and Analytical Framework.

Paladang, K. K., Indriani, S., \& Dirgantoro, K. P. S. (2018). Analisis Kesalahan Siswa Kelas VIII SLH Medan Dalam Mengerjakan Soal Matematika Materi Fungsi Ditinjau Dari Prosedur Newman. Journal of Holistic Mathematics Education.

Setiawan, R. 2019. juli 8, "PISA jadi standar internasional pendidikan di Indonesia" tersedia di https://tirto.id/mendikbud-pisa-jadi-standar-internasional-pendidikan-di-indonesia-edSa, Diakses tanggal 23 November 2019. 
Analisis Kesalahan Siswa Dalam Menyelesaikan Soal Pisa Konten Uncertainty dan Data, Evi Fazzilah, Kiki Nia Sania Effendi, Rina Marlina

Siswandi, E., Sujadi, I., \& Riyadi. (2016). Analisis kesalahan siswa dalam menyelesaikan masalah matematika kontekstual pada materi segiempat berdasarkan analisis Newman ditinjau dari perbedaan gender. Jurnal Elektronik Pembelajaran Matematika.

Sugiyono. 2018. Metode Penelitian Kualitatif. Bandung: Alfabeta

Sumargiyani, Yusnia, I., \& Adibah, Y. (2020). Analisis Kesalahan Dalam Menyelesaikan Soal Program Linear Berdasarkan Teori Newman. AdMathEdu, 9(2). 